\title{
Adatok a hazai adriai sallangvirág állományok természetvédelmi kezeléséhez
}

\author{
Biró Éva ${ }^{1}$ és Bódis Judit ${ }^{2}$ \\ ${ }^{1}$ Balaton-felvidéki Nemzeti Park Igazgatóság, \\ 8229 Csopak, Kossuth u. 16. \\ ${ }^{2}$ Pannon Egyetem, Georgikon Kar, Növénytudományi és Biotechnológiai Tanszék, \\ 8360 Keszthely, Festetics $u .7$. \\ e-mail: biroevi88@gmail.com
}

\begin{abstract}
Összefoglaló: A fajok természetvédelmi kezelésének megalapozásához elengedhetetlen az állományok ismerete. Az adriai sallangvirág (Himantoglossum adriaticum) természetvédelmi szempontból kiemelten fontos fajunk, melynek mind a négy nagy hazai populációjában felmértük a reproduktív töveket 2013 és 2017 között, s rögzítettük jellemzőiket. 34-179 virágzó tövet találtunk az egyes állományokban, melyek termésképzési sikere 9,2 és $61,7 \%$ között változott $(33,5 \pm 15,6 ; n=20)$. A keszthelyi és a sümegi populációban alacsonyabb (20\% körüli), a kőszegi és a nagyteveli populációkban magasabb (30-60\% körüli) termésképzési arányt tapasztaltunk. Az egyes jellemzök közül a magasság és a virágzathossz nem volt független egymástól, ennek megfelelően azonos módon változtak: termőhelyenként és évenként is szignifikánsan különböztek, s az évek és helyek kölcsönhatása is szignifikáns volt. A legkisebb változékonyságot a virágszám mutatta: csak a sümegi állomány tért el a többitől, itt szignifikánsan kisebb volt a virágszám. A termésszám és a termésképzési siker az évek és a helyek között is szignifikánsan eltért. A Corine felszínborítás alapján a keszthelyi és a sümegi állományok erdős-cserjés, míg a kőszegi és a nagyteveli állományok rét, illetve komplex mủvelésủ területen (zártkert) nőnek. A virágszám stabil jellemző, ám a termésképzési sikert az adott hely és az adott év környezeti tényezői befolyásolják. E háttértényezők felderítése kulcsfontosságú feladat a populációk megőrzése érdekében.
\end{abstract}

Kulcsszavak: virágzó egyedek száma, termésképzési siker, magasság, virágszám, felszínborítás

\section{Bevezetés}

A folyamatosan változó környezet állandó befolyással van a növényi közösségekre, ezért az egyes populációk dinamikájának megértéséhez hosszú távú és részletes vizsgálatokra van szükség (Tamm 1991). Napjainkban (részben a hagyományos tájhasználat megváltozása következtében) az élőhelyek gyors átalakulása figyelhető meg és ez sok faj számára jelent kihívást a fennmaradásukban. Az orchidea fajokat nagyfokú ökológiai alkalmazkodás jellemzi, ugyanakkor bonyolult élet- 
menetük, mikorrhiza- és megporzó kapcsoltságuk miatt fokozottan sérülékenyek (Waterman \& Bidartondo 2008).

A kosborok szeszélyes virágzási dinamikája igen régóta ismert és dokumentált. Kull (2002) összegezte az európai megfigyeléseket, mintegy 67 fajról talált legalább 3 éves (publikált) adatsort. Összesen 125 forrást sorolt fel, melyek közül ötvenben csak a virágzó egyedeket számolták évente egy adott területen. Kimutatatta, hogy a virágzó egyedek számának ingadozása lokálisan nagyobb, mint amit a nagyobb térléptékủ variáció során tapasztalunk.

A generatív egyedek számlálásával a felnőtt populáció egy részét mérjük csak fel, a populáció valódi méretéről, teljes egyedszámáról nem kapunk képet. Sokkal inkább azt mérjük ezzel, hogy a környezeti körülmények kedvezőek voltak-e a reprodukció számára vagy sem (Carey et al. 2002). Mivel a reprodukcióban az ikergumós orchideák esetében szinte kizárólag az ivaros szaporodásnak van szerepe, a virágzó egyedek száma figyelemre méltó demográfiai jellemző a populáció életképessége és túlélési esélye terén. Az állományok fitneszének jó jelzőszáma a termésképzési siker, különösen a nektárt nem termelö orchidea fajok esetében, melyek termésképzési sikere jóval alacsonyabb a jutalmazó fajokéhoz képest (Kindlmann \& Jersaková 2006).

A generatív tövek számlálása kedvelt, gyors és viszonylag kis hibával terhelt felmérési módszer a vegetatív tövek felméréséhez viszonyítva. A tőleveleket nehéz észrevenni, nagy területet szinte lehetetlen teljes alapossággal átfésülni, még több ember együttes munkája esetén is. Az állományok egyedszámának megállapítását az orchideák esetében tovább nehezíti a populációk évjáratonként jelentősen ingadozó egyedszáma és a dormans tövek esetenkénti jelentős részesedése.

Az adriai sallangvirág (Himantoglossum adriaticum $\mathrm{H}$. Baumann) egyike hazánk négy közösségi jelentőségü kosborfajának, Magyarországon fokozottan védett, természetvédelmi státusza veszélyeztetett (Király 2007). Szubmediterrán elterjedésű, táplálék ígéretével megtévesztő, kis areával rendelkező faj, emiatt hazai állományainak is nagy jelentősége van. Négy nagyobb és egy kisebb állománya ismert hazánkból, de az utóbbi években több új élőhelyére is rábukkantak Zala és Veszprém megyében (Óvári 2017, Koloszár András szóbeli közlése). Elsősorban száraz gyepi környezetben, félárnyékos helyeken fordul elő, de nem kizárólagosan elsődleges élőhelyeken; régóta ismertek a faj útszéli és felhagyott szőlőhegyeken lévö állományai is (Fekete et al. 2017).

Munkánkban azt szeretnénk igazolni, hogy az adriai sallangvirág reproduktív stratégiájának megértéséhez, a faj sikeres fennmaradásához szükséges tényezők feltárásához közelebb kerülhetünk a csupán a virágzó egyedek felmérésére koncentráló terepi vizsgálati módszerrel is. 


\section{Módszerek}

Az adriai sallangvirág mind a négy nagyobb, hazai populációjában (Köszeg, Nagytevel, Sümeg, Keszthely) vizsgáltuk a virágzó állomány nagyságát 20132017 között. Minden állományban törekedtünk az összes virágzó egyed felmérésére (kivéve 2015-ben és 2016-ban a sümegi és kőszegi populáció esetében, amikor igen sok egyed virágzott, hosszan elnyúlóan, ekkor csak a sérülésmentes, már termésben lévő példányok felvétele készült el). Mértük a virágzó hajtások magasságát és a virágzat hosszát, számoltunk a virágaikat, valamint rögzítettük a képződött termések számát. Számszerüsítettük a szaporodási sikert [termésképzési arány (fruitset) = termések száma/virágok száma]. Az egyes lelőhelyek öszszehasonlítását a Corine felszínborítás alapján végeztük. A statisztikai elemzések során egy- és kéttényezős varianciaanalízist, Tukey-tesztet és Kruskal-Wallis próbát használtunk.

\section{Eredmények}

A vizsgált időszakban (2013-2017) összesen 1903 virágzó adriai sallangvirág egyedet mértünk fel; az egyes állományokban évenként 34 (Keszthely, 2013) és 179 (Sümeg, 2014) között változott a virágzó tövek száma (1. táblázat). 2013-ban mindenütt alacsony számban lehetett virágzó példányokat megfigyelni, az országban összesen 180 virágzatot számláltunk. A 2014-töl 2016-ig tartó időszakban magas (484, legalább 451 és legalább 435), majd 2017-ben ismét alacsonyabb (353) számú reproduktív hajtást találtunk. 2017-ben először tapasztaltuk, hogy nem Sümegen (88 virágzat) volt a legtöbb virágzó tő, hanem Köszegen (147 virágzat). Összességében a kőszegi (638 virágzat) és a sümegi (627 virágzat) állományokban volt a legtöbb virágzat a vizsgált időszakban.

A hazai populációk termésképzési sikere 9,2 és $61,7 \%$ között változott a vizsgálat során. A keszthelyi és a sümegi populációban alacsonyabb (jellemzően $20 \%$ körüli éves átlagok), míg a kőszegi és a nagyteveli populációkban magasabb (3060\% körüli éves átlagok) termésképzési arányt tapasztaltunk (1. táblázat).

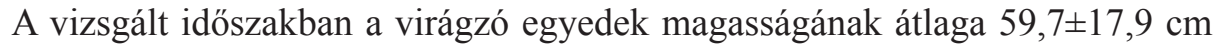
$(\min =14, \max =120)$, a virágzathossz átlagosan $26,7 \pm 10,0 \mathrm{~cm}(\min =3, \max =67)$ volt. Az egyedek $76 \%$-a $20-50$ db virágot fejlesztett, a virágzatonkénti virágszám átlaga $34,7 \pm 12,9 \mathrm{db}(\min =4, \max =95)$. A képződött termések száma a vizsgált tövek 57\%-nál tíz vagy az alatti volt (átlag $=11,7 \pm 12,2 \mathrm{db}, \min =0, \max =68$ ), a termésképzési arány átlaga $31,4 \pm 27,9 \%$ ( $\mathrm{min}=0 \%, 331$ esetben; $\max =100 \%, 6$ esetben). 
1. táblázat. Az adriai sallangvirág vizsgált állományainak egyedszáma és termésképzési sikere 2013 és 2017 között.

\begin{tabular}{lccccc}
\hline \multicolumn{1}{c}{ Település } & Év & Egyedszám & Virágszám & Termésszám & $\begin{array}{c}\text { Termésképzé- } \\
\text { si siker (\%) }\end{array}$ \\
\hline Keszthely & 2017 & 76 & 2525 & 404 & 16,0 \\
Keszthely & 2016 & 90 & 3206 & 598 & 18,7 \\
Keszthely & 2015 & 76 & 2835 & 817 & 28,8 \\
Keszthely & 2014 & 53 & 1862 & 408 & 21,9 \\
Keszthely & 2013 & 34 & 1197 & 110 & 9,2 \\
Sümeg & 2017 & 88 & 2799 & 578 & 20,7 \\
Sümeg & 2016 & $135^{*}$ & 4063 & 873 & 21,5 \\
Sümeg & 2015 & $170^{*}$ & 5400 & 1045 & 19,4 \\
Sümeg & 2014 & 179 & 5278 & 1262 & 23,9 \\
Sümeg & 2013 & 54 & 1721 & 403 & 23,4 \\
Köszeg & 2017 & 147 & 5604 & 3129 & 55,8 \\
Köszeg & 2016 & $142^{*}$ & 5545 & 1544 & 27,8 \\
Köszeg & 2015 & $128 *$ & 4873 & 2141 & 43,9 \\
Köszeg & 2014 & 171 & 5883 & 2211 & 37,6 \\
Köszeg & 2013 & 50 & 1764 & 721 & 40,9 \\
Nagytevel & 2017 & 42 & 1576 & 692 & 43,9 \\
Nagytevel & 2016 & 68 & 2345 & 1005 & 42,9 \\
Nagytevel & 2015 & 77 & 3074 & 1649 & 53,6 \\
Nagytevel & 2014 & 81 & 2981 & 1712 & 57,4 \\
Nagytevel & 2013 & 41 & 1477 & 911 & 61,7 \\
\hline A vizǵ́latba bevont & & & &
\end{tabular}

* A vizsgálatba bevont egyedszám.

A magasság és a virágzathossz nem volt független egymástól (virágzathossz $=-2,71+0,491 \times$ magasság; $R^{2}=0,769$ ), ennek megfelelően azonos módon változtak: termőhelyenként (magasság: $\mathrm{F}_{3}=182,229 ; \mathrm{p}<0,0001$; virágzathossz: $\mathrm{F}_{3}=54,507 ; \mathrm{p}=0,000$ ) és évenként (magasság: $\mathrm{F}_{4}=21,049$; $\mathrm{p}<0,0001$ ); virágzathossz: $\left.\mathrm{F}_{4}=17,193 ; \mathrm{p}=0,000\right)$ is szignifikánsan különböztek, $\mathrm{s}$ az évek és helyek kölcsönhatása is szignifikáns (magasság: $\mathrm{F}_{3,4}=5,493 ; \mathrm{p}<0,0001$; virágzathossz: $\mathrm{F}_{3,4}=5,813 ; \mathrm{p}<0,0001$ ) volt.

A magasság és a virágszám közötti összefüggés gyengébb (virágszám = $6,79+0,467$ x magasság; $\mathrm{R}^{2}=0,423$ ). A virágszám esetében csak a termőhely $\left(F_{3}=23,573 ; p<0,0001\right)$ és az évhatás $\left(F_{4}=2,714 ; p=0,029\right)$ bizonyult szignifikánsnak, a kölcsönhatásuk nem $\left(\mathrm{F}_{3,4}=1,415 ; \mathrm{p}=0,152\right)$.

A virágzathosszban mind a négy állomány szignifikánsan eltért egymástól. Sümegen voltak a legrövidebbek a virágzatok, amit Nagytevel, aztán Keszthely 
követ, míg Köszegen voltak a leghosszabbak. A sümegi állomány egyedei bizonyultak a legalacsonyabbnak, a kőszegiek a legmagasabbnak, a nagyteveli és a keszthelyi egyedek köztes helyzetet foglaltak el (2. táblázat).

2. táblázat. Az egyes adriai sallangvirág populációk egyedeinek átlagértékei, és a Tukey teszt eredménye. A betük az egyező varianciákat jelölik.

\begin{tabular}{lcccccc}
\hline & $\begin{array}{c}\text { Egyedszám } \\
(\mathrm{db})\end{array}$ & $\begin{array}{c}\text { Magasság } \\
(\mathrm{cm})\end{array}$ & $\begin{array}{c}\text { Virágzat } \\
\text { hossza }(\mathrm{cm})\end{array}$ & $\begin{array}{c}\text { Virágok } \\
\text { száma }(\mathrm{db})\end{array}$ & $\begin{array}{c}\text { Tokok szá- } \\
\text { ma }(\mathrm{db})\end{array}$ & $\begin{array}{c}\text { Termésképzé- } \\
\text { si siker }(\%)\end{array}$ \\
\hline Sümeg & 627 & $49,5^{\mathrm{a}}$ & $23,1^{\mathrm{a}}$ & $30,8^{\mathrm{a}}$ & 6,6 & 21 \\
Nagytevel & 309 & $57,7^{\mathrm{b}}$ & $25,1^{\mathrm{b}}$ & $35,3^{\mathrm{b}}$ & 19,3 & 51,0 \\
Keszthely & 329 & $58,3^{\mathrm{b}}$ & $26,8^{\mathrm{c}}$ & $37,1^{\mathrm{b}}$ & 7,1 & 18,5 \\
Kőszeg & 638 & $71,6^{\mathrm{c}}$ & $30,8^{\mathrm{d}}$ & $37,1^{\mathrm{b}}$ & 15,3 & 38,9 \\
\hline
\end{tabular}

A legkisebb változékonyságot a virágszám mutatta: csak a sümegi állomány tért el a többitől, itt szignifikánsan kisebb volt a virágszám. A termésszám és a termésképzési siker az évek között (termésszám: $\chi_{4}^{2}=22,484 ; \mathrm{p}<0,0001$, termésképzési siker: $\chi_{4}^{2}=28,959 ; \mathrm{p}<0,0001$ ) és a helyek között (termésszám: $\chi_{3}^{2}=294,073$; $\mathrm{p}<0,0001$, termésképzési siker: $\left.\chi_{3}^{2}=301,218 ; \mathrm{p}<0,0001\right)$ is szignifikánsan eltért. A legalacsonyabb értékeket a keszthelyi és sümegi állomány esetében figyeltünk meg, a legmagasabb termésszámot és termésképzési sikert pedig a nagyteveli állománynál kaptuk (2. táblázat).

A felszínborítási adatok alapján a keszthelyi és a sümegi állományok erdős, illetve erdős-cserjés területen fordulnak elő, míg a kőszegi és a nagyteveli állományok rét, illetve komplex müvelésü területen (zártkert) nőnek (1. ábra).

\section{Értékelés}

Régóta meglévő ismeret, hogy az orchideák virágzó példányainak száma szélsőségesen ingadozik, ez alapján virágzási szempontból beszélünk ,jó” és „rossz” évekröl, mely az összes hazai állományra egyformán vonatkozik. Akkor beszélünk ,jó” orchideás évröl, amikor a virágzó egyedek száma magas és akkor „rossz” orchideás évről, amikor a virágzó egyedek száma alacsony (Németh \& Seregélyes 1981). Ez azzal függ össze, hogy a növények számára kedvezőek vagy kedvezőtlenek a körülmények. Pfeifer et al. (2006a, 2006b) eredményei alapján a virágzó egyedek számát alakító legfőbb tényezőnek a virágzást megelöző és az adott év időjárási körülményei bizonyultak. Magyarországon a négy állomány virágzási erélye nem feltétlenül mozog együtt. Legszembetünőbben 2017-ben figyelhettük ezt meg, amikor Keszthelyen és Köszegen ,jó" év volt, azaz magas volt a virágzó tövek száma, míg Sümegen „rossz”, azaz kevés volt a virágzó tő. 


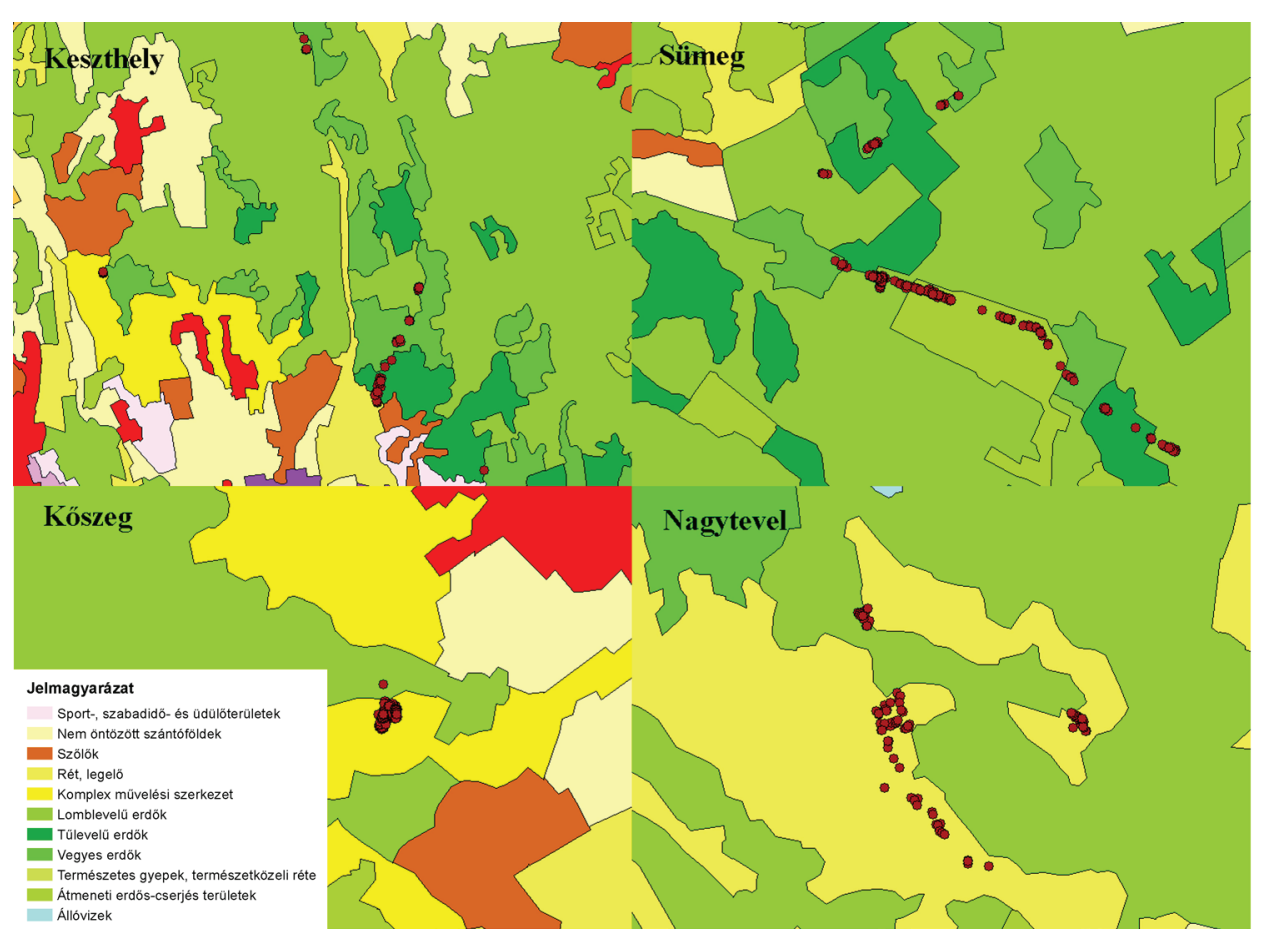

1. ábra: Az egyes állományok elhelyezkedése (fekete pontokkal jelölve a virágzó sallangvirág egyedek) a CORINE felszínborítási térképén. Keszthely $M=1: 40$ 000; Sümeg M=1:20 000; Köszeg M=1:10 000; Nagytevel M=1:10 000

A csapadék éves mennyisége minden évben Köszegen volt a legmagasabb [1]; ez biztosan befolyásolta a virágzó egyedek számát, s ennek hatása a hajtásmagasságban is megnyilvánult. A sallangvirágok nemcsak kedvező időjárás esetén hoznak magas virágzatokat, hanem akkor is, ha árnyékban, cserjék, fák alatt virágoznak. Ez utóbbi esetben azonban a felnyurgult hatások megdölnek, termés alig, vagy egyáltalán nem képződik rajtuk (Zadravec et al. 2014).

Kőszegen és Nagytevelen tapasztaltunk magas termésképzési sikert a vizsgált időszak során. Kőszegen az egykori szőlők helyén kialakult fajgazdag kaszálóréteken, gyümölcsfákkal beültetett és becserjésedett parcellákon fordulnak elö az egyedek. E komplex művelésủ (zártkerti) élőhely jó feltételeket teremt az orchideák számára, ám kezelési szempontból nehézséget jelent, hogy magántelkeken nőnek a sallangvirágok. A kőszegi állomány sorsa jórészt azon múlik, hogy a területek tulajdonosaival hosszú távon is fenn tudja-e tartani a természetvédelem a mostani jó viszonyt.

Nagytevelen szárazabb termőhelyen nőnek a növények; ahol félárnyékban érzik jól magukat a virágzó tövek, a nyílt gyep mellett cserjések szegélyén is 
megjelennek, ahogy azt mások is tapasztalták (Slaviero et al. 2016). Időszakosan elvégzett cserjeirtás (túlzott becserjésedés megakadályozása) fontos a szaporodási siker szempontjából, mert a cserjeborítás növekedése csökkenti a termésszámot (Jacquemyn et al. 2002, Fekete et al. 2017), de száraz években negatív hatású is lehet. Ilyenkor a fennsík cserjeirtott részein besültek a virágzatok, de a csapadékos években sok virágzatot találtunk ugyanitt, s ezeken sok termés képződött. A 2013-ban Nagytevelen tapasztalt rendkívül magas termésképzési sikert $(61,7 \%)$ a közelbe telepített háziméh kaptárak is befolyásolták (Biró et al. 2015).

Keszthelyen és Sümegen alacsony volt a reproduktív siker a vizsgált évek során. Bár Keszthelyen is nagy számban figyeltünk meg magas növényeket, de ezt sok esetben az árnyékolás miatti megnyúlás okozta. A sümegi növények bizonyultak a legalacsonyabbaknak, $\mathrm{s}$ a virágszámuk is alacsonyabb volt, mint a többi állományé.

Az adriai sallangvirág esetében a virágszám bizonyult a legkevésbé változó jellemzőnek. Hasonlóan stabil bélyegnek találták a virágszámot a Dactylorhiza lapponica (Øien \& Moen 2002), valamint az észak-amerikai Tipularia discolor és a Liparis lilifolia esetében (Whigham \& O’Neil 1991) is, míg az Ophrys apifera-nál és a Platanthera bifolia-nál évjáratfüggőnek mutatkozott ez a jellemző (Brzosko 2003, Wells \& Cox 1991).

A virágszám stabilitása mellett a termésszám és a termésképzési siker helyenként és évenként is jelentős mértékben változott vizsgálataink idején. Ez arra utalhat, hogy az adriai sallangvirág reproduktív egyedei megbízhatóan azonos virágszámmal virágoznak, ám a termésképzés sikerét az adott hely és az adott év környezeti tényezői befolyásolják. E háttértényezők felderítésére azonban már nem elegendő csak a virágzó egyedekre koncentrálni. A termésképzési sikert befolyásoló tényezők felderítése kulcsfontosságú feladat a populációk megőrzése érdekében.

Köszönetnyilvánítás - Molnár V. Attilának köszönjük a szakmai konzultációkat, Sisák Istvánnak pedig a statisztikai elemzés során nyújtott segítségét. A publikáció elkészitését a EFOP-3.6.3-VEKOP-16-2017-00008 számú projekt támogatta. A projekt az Európai Unió támogatásával, az Európai Szociális Alap társfinanszírozásával valósult meg.

\section{Irodalomjegyzék}

Biró, É., Bódis, J., Nagy, T., Tökölyi, J. \& Molnár, V. A. (2015): Honeybee (Apis mellifera) mediated increased reproductive success of a rare deceptive orchid. - Appl. Ecol. Env. Res. 13: 181-192.

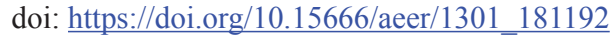

Brzosko, E. (2003): The dynamics of island populations of Platanthera bifolia in the Biebrza National Park (NE Poland). - Ann. Bot. Fenn. 40: 243-253. 
Carey, P. D., Farrell, L. \& Stewart, N. F. (2002): The sudden increase in the abundance of Himantoglossum hircinum in England in the past decade and what has caused it. - In: Kindlmann, P., Willems, J. \& Whigham, D. F. (eds): Trends and fluctuations and underlying mechanisms in terrestrial orchid populations. Backhuys Publishers, Leiden, pp. 187-208.

Fekete, R., Nagy, T, Bódis, J., Biró, É., Löki, V., Süveges, K., Takács, A., Tökölyi, J. \& Molnár, V. A. (2017): Roadside verges as habitats for endangered lizard-orchids (Himantoglossum spp.): Ecological traps or refuges? - Sci. Total Envir. 607-608: 1001-1008. doi: https://doi.org/10.1016/j. scitotenv.2017.07.037

Jacquemyn, H., Brys, R. \& Hermy, M. (2002): Flower and fruit production in small populations of Orchis purpurea and implications for management. - In: Kindlmann, P., Willems, J. \& Whigham, D. F. (eds): Trends and fluctuations and underlying mechanisms in terrestrial orchid populations. Backhuys Publishers, Leiden, pp. 67-84.

Kindlmann, P. \& Jersakova, J. (2006): Effect of floral display on reproductive success in terrestrial orchids. - Folia Geobot. 41: 47-60. doi: https://doi.org/10.1007/BF02805261

Király, G. (szerk.) (2007): Vörös Lista. A magyarországi edényes flóra veszélyeztetett fajai. - Saját kiadás, Sopron, $73 \mathrm{p}$.

Kull, T. (2002): Population dynamics of north temperate orchids. - In: Kull, T. \& Arditti, J. (eds): Orchid biology: reviews and perspectives, VIII. Kluwer Academic Publishers, Dordrecht, pp. 139-165.

Németh, F. \& Seregélyes, T. (1981): Ne bántsd a virágot! Néhány ritkaság a hazai flórából. OKTHMTI, Budapest. $131 \mathrm{p}$.

Øien, D-I. \& Moen, A. (2002): Flowering and survival of Dactylorhiza lapponica and Gymnadenia conopsea on the Solendet Nature Reserve, Central Norway. - In: Kindlmann, P., Willems, J. \& Whigham, D. F. (eds): Trends and fluctuations and underlying mechanisms in terrestrial orchid populations. Backhuys Publishers, Leiden, pp. 3-22.

Óvári, M. (2017): A Himantoglossum adriaticum Baumann a Kelet-Zalai-dombságban. - Kitaibelia 22: 297-303. doi: https://doi.org/10.17542/kit.22.297

Pfeifer, M., Heinrich, W. \& Jetschke, G. (2006a): Climate, size and flowering history determine flowering pattern of an orchid. - Bot. J. Linn. Soc. 151: 511-526. doi: https://doi.org/10.1111/ j.1095-8339.2006.00539.x

Pfeifer, M., Wiegand, K., Heinrich, W. \& Jetschke, G. (2006b): Long-term demographic fluctuations in an orchid species driven by weather: implications for conservation planning. - J. Appl Ecol. 43: 313-324. doi: https://doi.org/10.1111/j.1365-2664.2006.01148.x

Slaviero, A., Del Vecchio, S., Pierce, S., Fantinato, E., \& Buffa, G. (2016): Plant community attributes affect dry grassland orchid establishment. - Plant Ecol. 217: 1533-1543. doi: https://doi. org/10.1007/s11258-016-0666-X

Tamm, C. (1991): Behaviour of some orchid populations in a changing environment. Observations on permanent plots, 1943-1990. - In: Wells, T. C. E. \& Willems, J. H. (eds): Population ecology of terrestrial orchids. SPB Academic Publishing, The Hague, The Netherlands, pp. 1-13.

Waterman, R. J. \& Bidartondo, M. I. (2008): Deception above, deception below: linking pollination and mycorrhizal biology of orchids. - J. Exp. Bot. 59: 1085-1096. doi: https://doi.org/10.1093/ jxb/erm366

Wells, T. C. E. \& Cox, R. (1991): Demographic and biological studies on Ophrys apifera: some results from a ten year study. - In: Wells, T. C. E. \& Willems, J. H. (eds): Population ecology of terrestrial orchids. SPB Academic Publishing, The Hague, The Netherlands, pp. 47-63.

Whigham, D. F. \& O'Neil, J. (1991): The dynamics of flowering and fruit production in two eastern North American terrestrial orchids, Tipularia discolor and Liparis lilifoli. - In: Wells, T. C. E. \& 
Willems, J. H. (eds): Population ecology of terrestrial orchids. SPB Academic Publishing, The Hague, The Netherlands, pp. 89-101.

Zadravec, V., Zadravec, M. \& Zadravec, M. (2014): Orchids of Vejalnica and Krc (Medvednica). Glasnik Hrvatskog botanickog društva 2: 4-12.

[1]:https://met.hu/eghajlat/magyarorszag_eghajlata/eghajlati visszatekinto/elmult evek idojarasa/ main.php?no $=0 \&$ ful $=$ csapadek

\title{
Data to the management of the Adriatic lizard orchid populations in Hungary
}

\author{
Éva Biró ${ }^{1}$ and Judit Bódis ${ }^{2}$ \\ ${ }^{1}$ Balaton-felvidéki National Park Directorate, H-8229 Csopak, Kossuth u. 16., Hungary \\ ${ }^{2}$ Department of Plant Sciences and Biotechnology, Georgikon Faculty, University of \\ Pannonia, H-8360 Keszthely, Festetics u. 7., Hungary \\ e-mail: biroevi88@gmail.com
}

The effective protection of species requires a detailed knowledge of their biology. The Adriatic Lizard orchid (Himantoglossum adriaticum H. Baumann) is a Natura 2000, CITES species, and a strictly protected plant in Hungary. This orchid has four larger and one smaller populations in Hungary (other satellite locations are also known). We counted the flowering individuals in all of the larger populations in Hungary between 2013 and 2017. Altogether 1903 inflorescences were tagged to record the height of the flowering stalk, the length of inflorescence and the number of flowers and fruits. We found 34-179 flowering shoots in each population per year. The reproductive success varied between 9.2 and $61.7 \%$ (mean $=33.5 \pm 15.6, n=20)$ in the populations. There were lower (typically around 20\% annual averages) fruit set in Keszthely and Sümeg, and higher in Köszeg and Nagytevel (around 30-60\% annual averages). Among the traits, the height of the shoot and the length of the inflorescence were not independent from each other, accordingly they changed in the same way: they differed significantly between places and years too, and the interaction of years and places was also significant. The smallest variability was shown by the number of flowers: only the Sümeg population differed from the others, the flower number was significantly lower here. The number of fruits and reproductive success also differed significantly between years and places. On the basis of the Corine surface cover, the Keszthely and Sümeg populations occur in forested areas or in forested and scrubland mosaic, while the population of Köszeg and Nagytevel grow in a complex of meadow and cultivated areas. The number of the flowers in the inflorescences is a stable trait, but reproductive success is influenced by the location and the environmental factors of the given year. Recognizing these background factors is a key task for preserving populations.

Keywords: number of flowering individuals, reproductive success, height of the shoot, number of flowers, surface cover 